\title{
PENGENDALIAN KUALITAS PADA PROSES PENERIMAAN BARANG UNTUK MENURUNKAN DEFECT PRODUCT DENGAN PENDEKATAN SIX SIGMA
}

\author{
Annisa Indah Pratiwi ${ }^{1}$, Ragil Yuli Santosa ${ }^{2}$ \\ 1,2Jurusan Teknik Industri, Fakultas Teknik dan Ilmu Komputer, Universitas Buana Perjuangan Karawang \\ Jl. HS. Ronggowaluyo Telukjambe Timur Karawang, \\ Email: annisa.indah@ubpkarawang.ac.id
}

\begin{abstract}
The industrial revolution 4.0 has an impact on the progress of a global business, including in Indonesia. One of the companies affected is the Logistics Company. In this research, a logistics company is a company engaged in warehousing and logistics services or 3PL (third party logistics service providers). Based on the research results, it is known that there are five types of products with the highest number of defects in the last six months, namely ER180, IA195, IA120, SL235 and IA220 products. From the Pareto diagram, it is known that the ER180 product is the product that has the highest defect percentage among other products, namely as much as 52\%. The processing results obtained an average DPMO value of 185.68538 failures per one million and a sigma level of about 5.06 with a COPQ level of 5-15\%. Based on data analysis using Failure Mode and Effect Analysis, there are six types of product defects, namely dented packaging, damaged outer cartons, leaking products, rotten products, inappropriate product dimensions and plain packaging. The main causes of product defects are MHE operators who are not careful, the use of damaged wooden pallets and the lack of lighting in the work area. Based on the analysis using FTA and FMEA, the proposed quality improvement for the company, namely conducting training and training so that employee knowledge and skills increase, selection of pallets according to standards and adding lighting in the work area.
\end{abstract}

Keywords: Quality; Warehouse; Six Sigma; FTA; FMEA

\begin{abstract}
ABSTRAK
Revolusi industri 4.0 berdampak pada kemajuan suatu bisnis global termasuk di Indonesia. Salah satu perusahaan yang bedampak yaitu Perusahaan Logistik. Dalam penelitian ini dilakukan pada Perusahaan logistik merupakan perusahaan yang bergerak dibidang jasa pergudangan dan logistik atau 3PL (third party logistic service providers). Berdasarkan hasil penelitian maka diketahui bahwa terdapat lima jenis produk dengan jumlah defect tertinggi selama enam bulan terakhir yaitu produk ER180, IA195, IA120, SL235 dan IA220. Dari diagram pareto, diketahui produk ER180 merupakan produk yang mempunyai persentase defect tertinggi diantara produk lain yaitu sebanyak 52\%. Hasil pengolahan diperoleh rata-rata nilai DPMO sebesar 185,68538 kegagalan per satu juta dan level sigmanya sekitar 5,06 dengan tingkat COPQ sebesar 5-15\%. Berdasarkan analisis data menggunakan Failure Mode and Effect Analysis terdapat enam jenis cacat produk yaitu kemasan penyok, karton luar rusak, produk bocor, produk busuk, dimensi produk tidak sesuai dan kemasan polos. Penyebab utama terjadinya produk defect yaitu faktor operator MHE yang tidak hati-hati, penggunaan palet kayu yang rusak dan kurangnya pencahayaan di area kerja. Berdasarkan analisis menggunakan FTA dan FMEA, usulan perbaikan kualitas untuk perusahaan, yaitu mengadakan pelatihan dan training agar pengetahuan dan skill karyawan meningkat, pemilihan palet yang sesuai standar dan penambahan lampu pencahayaan pada area kerja.
\end{abstract}

Kata kunci: Kualitas; Gudang; Six sigma; FTA; FMEA 


\section{PENDAHULUAN}

Perusahaan Jasa Pergudangan dan Logistik adalah suatu perusahaan 3PL yang menjadi pihak ke tiga dalam hal penyimpanan dan pengiriman produk ke konsumen di salah satu kota propinsi Jawa Barat. Produk yang di simpan adalah produk makanan sehari hari atau biasa dikenal dengan istilah FMCG yaitu "Fast Moving Consumer Goods". Produk dari perusahaan produsen akan masuk ke gudang perusahaan 3PL dengan melalui beberapa proses yaitu penerimaan, penyimpanan dan pengiriman ke konsumen. Proses penerimaan produk atau proses "inbound" adalah proses yang sangat penting dalam hal kualitas produk sebelum di simpan dan di kirim ke konsumen. Penggunaan teknologi internet dalam pengecekan produk masuk ke gudang 3PL merupakan suatu inovasi baru dalam menjawab tantangan revolusi industri 4.0, namun dalam pelaksanaannya tidak semudah yang di harapkan. Produk-produk yang di terima dari produsen akan di check berdasarkan kualiatas fisik kemasan, jumlah, masa kadaluarsa dan kesesuaian dengan dokumennya. Dari hal tersebut sering kali ditemukan produk dengan kondisi cacat dan tidak sesuai dengan identitas produknya yang disebabkan oleh ketidaktelitian man power dalam produsen untuk memakai jasa dari perusahaan 3PL tersebut. Pada penelitian ini telah ditemukan 300 lebih jenis produk yang di simpan di dalam gudang namun dalam hal ini hanya akan mencari lima produk dengan jumlah cacat produk tertinggi. Penelitian ini perlu dilakukan analisa lebih dalam agar dapat mencari faktor-faktor penyebab munculnya masalah serta ide-ide perbaikan yang dapat diaplikasikan dengan tujuan agar dapat meminimalisasikan jumlah kecacatan. Diharapkan perusahaan dapat meningkatkan kepuasan client dengan cara menurunkan jumlah defect produk agar dapat memaksimalkan produktivitas perusahaan dan mampu menjamin kualitas produk produk yang di terima konsumen dengan menentukan perbaikan perbaikan yang harus diterapkan guna meningkatkan kualitas produk. Penelitian sejenis dilakukan oleh Pratama dan Suhartini (2019), dengan judul Analisis Kecacatan Produk dengan Metode Seven Tools dan FTA dengan Mempertimbangkan Nilai Risiko berdasarkan Metode FMEA dengan objek kecacatan plat baja. Dalam penelitian tersebut didapatkan hasil Tingkat kecacatan yang paling dominan diantaranya laminasi $41 \%$, plat reject $32 \%$, dan plat missroll $24 \%$. Dengan menggunakan metode FMEA nilai RPN yang paling tinggi yaitu 192, 162, dan 120 yang terdapat pada proses 3-high roughing \& finishing mill.

\section{METODE PENELITIAN}

\section{Jenis Penelitian}

Jenis penelitian yaitu penelitian kuantitatif dengan mereferensikan beberapa teori, diantaranya yaitu terkait pengendalian kualitas, seven tools, FMEA dan DMAIC. Menurut Elliot dalam Iskandar (2008) kualitas merupakan sesuatu yang memiliki tujuan yang berbeda, sesuai dengan selera tiap individu, waktu dan tempat. Sedangkan menurut Praptono dalam Irwan et all (2015) Pengendalian Kualitas adalah proses penggunaan tools yang ekonomis dan sesuai standar guna menguji kualitas suatu produk. Menurut Montgomery dalam Irwan et all (2015) pengendalian kualitas merupakan kegiatan yang membandingkan suatu produk terhadap standar produk tersebut guna memenuhi standar mutu apabila ada perbedaan dalam proses perbandingan. Salah satu seven tool yaitu diagram pareto. Menurut Alfredo Pareto (1848-1923) diagram pareto adalah suatu gambaran yang mengurutkan klasifikasi data dari kiri ke kanan menurut urutan rangking tertingki hingga terendah. Diagram pareto ini digunakan untuk menentukan langkah yang harus diambil sebagai upaya dalam menyelesaikan masalah. Menurut (Arini, 2017) Failure Mode and Effect Analysis (FMEA) merupakan metodologi terstuktur untuk mengidentifikasi dan menganalisis kegagalan /kesalahan (failure) yang sudah terjadi atau yang mungkin akan terjadi dengan tujuan mencegah kegagalan tersebut yang memberikan dampak negatif pada hasil sebuah proses. Dalam implementasi project Six Sigma, FMEA digunakan untuk mengidentifikasikan permasalahan, melakukan pengumpulan data, menganalisis usaha-usaha voice of custumer, prosedur, dan pelaksanaan inisiatif six sigma. Tahap awal dalam penyusunan FMEA adalah Menentukan nilai Risk Priority Number (RPN). Menurut (Stamatis, 1995) RPN menegaskan tingkat prioritas dari suatu failure dan nilai RPN bergantung pada nilai severity rating, occurance rating, dan detection rating. Rumus yang digunakan untuk menghitung RPN yaitu:

$\mathrm{RPN}=$ Severity rating $\mathrm{x}$ Occurance rating $\mathrm{x}$ Detection rating

$$
=\mathrm{S} \times \mathrm{O} \times \mathrm{D}
$$


Konsep DMAIC (define-measure-analyze-improve control) merupakan metode yang paling sering digunakan dalam penerapan metode sig sigma yang bertujuan untuk peningkatan kualitas. Metode six sigma dengan konsep DMAIC ini pertama kali diterapkan oleh dua perusahaan di Amerika yaitu General Electric dan Motorola pada tahun 1980an sampai pada tahun 1990 yang terbukti memberikan dampak positif terhadap bisnisnya. Tahap define merupakan tahap awal identifikasi suatu masalah masalah yang muncul pada proses kerja. Tujuan dari tahap measure adalah mencari peluang untuk perbaikan atau peningkatan kinerja dan menetapkan ukuran yang akan ditetapkan menjadi basis pengukuran peningkatan kinerja setelah project six sigma di implementasikan (Arini, 2017). Tujuan dari tahap Analyze adalah untuk memprioritaskan langkah langkah perbaikan yang menjadi penyebab kegagalan hingga ke akar permasalahannya. Tahap improve ini merupakan suatu upaya dalam menghilangkan berbagai penyebab kegagalan proses dan cacat produk dimana suatu langkah perbaikan harus ditargetkan berdasarkan hal hal yang menjadi prioritas utama dengan berdasar tingkat kecacatan yang tertinggi dari beberapa sumber kegagalan dan kecacatan yang sudah diketahui di tahap analyze.

\section{Waktu dan Tempat Penelitian}

Waktu penelitian dimulai Oktober 2019 sampai dengan September 2019 dan tempat penelitian yaitu perusahaan jasa pergudangan dan logistik yang berlokasi di salah satu kota propinsi Jawa Barat.

\section{Target/Subjek Penelitian}

Penelitian ini akan membahas tentang kecacatan produk yang diterima dalam proses penerimaan barang dari perusahaan jasa pergudangan dan logistik yang berlokasi di salah satu kota propinsi Jawa Barat. Hal hal yang terkait dengan penelitian ini adalah mengenai issue yang menimbulkan kecacatan produk dan Kualitas dari produk yang diterima selama di proses penerimaan barang dari pihak produsen.

\section{Prosedur Penelitian}

Penelitian dilakukan dengan Langkah-langkah sebagai berikut:

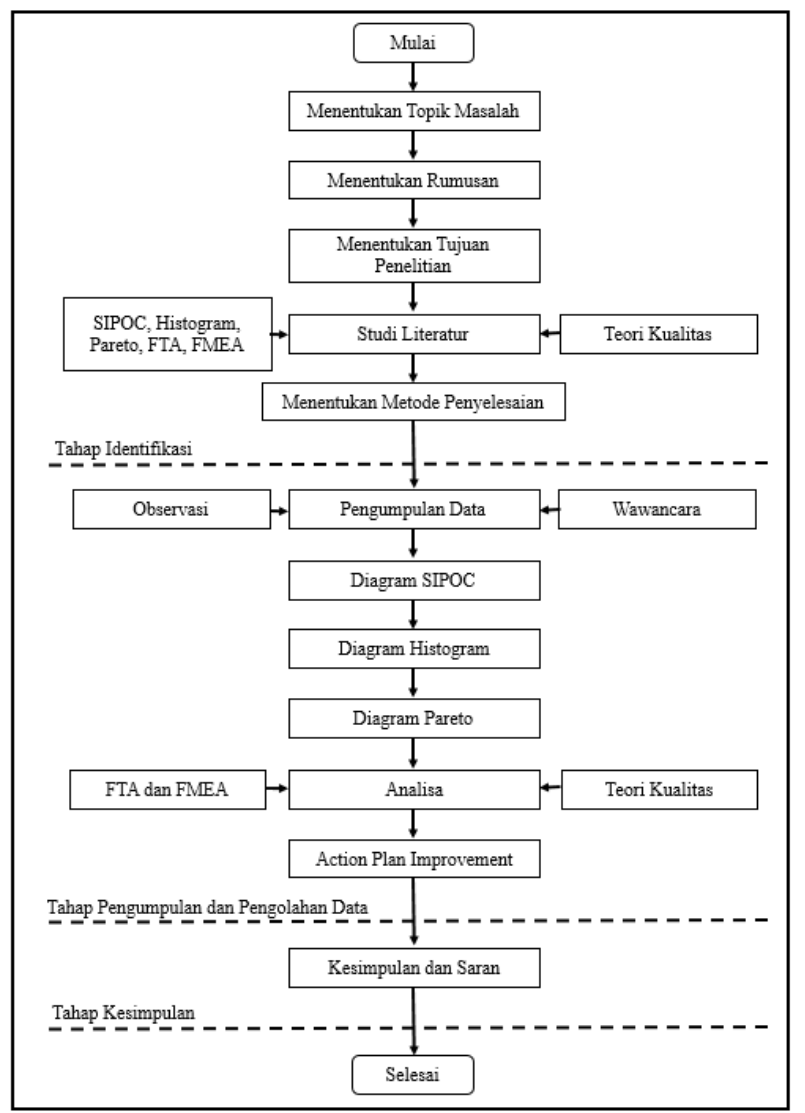

Gambar 1. Diagram Alir Penelitian 


\section{Data, Instrumen, dan Teknik Pengumpulan Data}

Proses pengumpulan data dimulai dengan cara mengidentifikasi masalah masalah yang terjadi. Pengumpulan data primer dilakukan dengan cara mencari hal hal yang menimbulkan masalah terkait kecacatan produk baik dilakukan secara observasi langsung di bagian proses penerimaan barang maupun dengan cara wawancara langsung kepada karyawan di bagian proses penerimaan barang tersebut. Pengumpulan data sekunder dengan mengumpulkan data-data historis.

\section{Teknik Analisis Data}

Berikut ini merupakan beberapa analisa data yang digunakan dalam penelitian ini:

1. Data produk yang masuk melalui proses penerimaan barang, untuk mengetahui jumlah produk yang masuk melalui proses penerimaan barang selama enam bulan terakhir.

2. Data produk cacat, untuk mengetahui jumlah produk cacat yang masuk melalui proses penerimaan barang.

3. Mencari jumlah cacat terbesar dengan cara membuat diagram pareto.

4. Melakukan analisa dari kecacatan produk tersebut dengan membuat diagram pohon, sehingga dapat diketahui faktor penyebab kecacatan dari jenis produk tersebut.

5. Setelah dilakukan analisa dengan diagram pohon tersebut, maka langkah selanjutnya adalah dengan menyusun alternatif-alternatif perbaikan dalam mencegah kecacatan jenis produk tersebut agar tidak terulang lagi.

6. Data kecacatan produk tersebut juga dapat dijadikan acuan untuk menyusun FMEA serta untuk mengetahui score RPN-nya.

\section{HASIL DAN PEMBAHASAN}

Pemetaan proses inbound akan di jelaskan dengan menggunakan rich picture diagram. Rich picture diagram digunakan untuk menggambarkan keseluruhan proses bisnis secara jelas dengan gambar dan hubungan antar gambar tersebut dengan penjelasan singkat agar orang yang melihat dapat dengan mudah untuk mengerti dan memahami maksud dari gambar tersebut. Berikut ini merupakan pemetaan proses inbound dan outbound pada departemen operation zona 3 dengan menggunakan rich picture diagram.

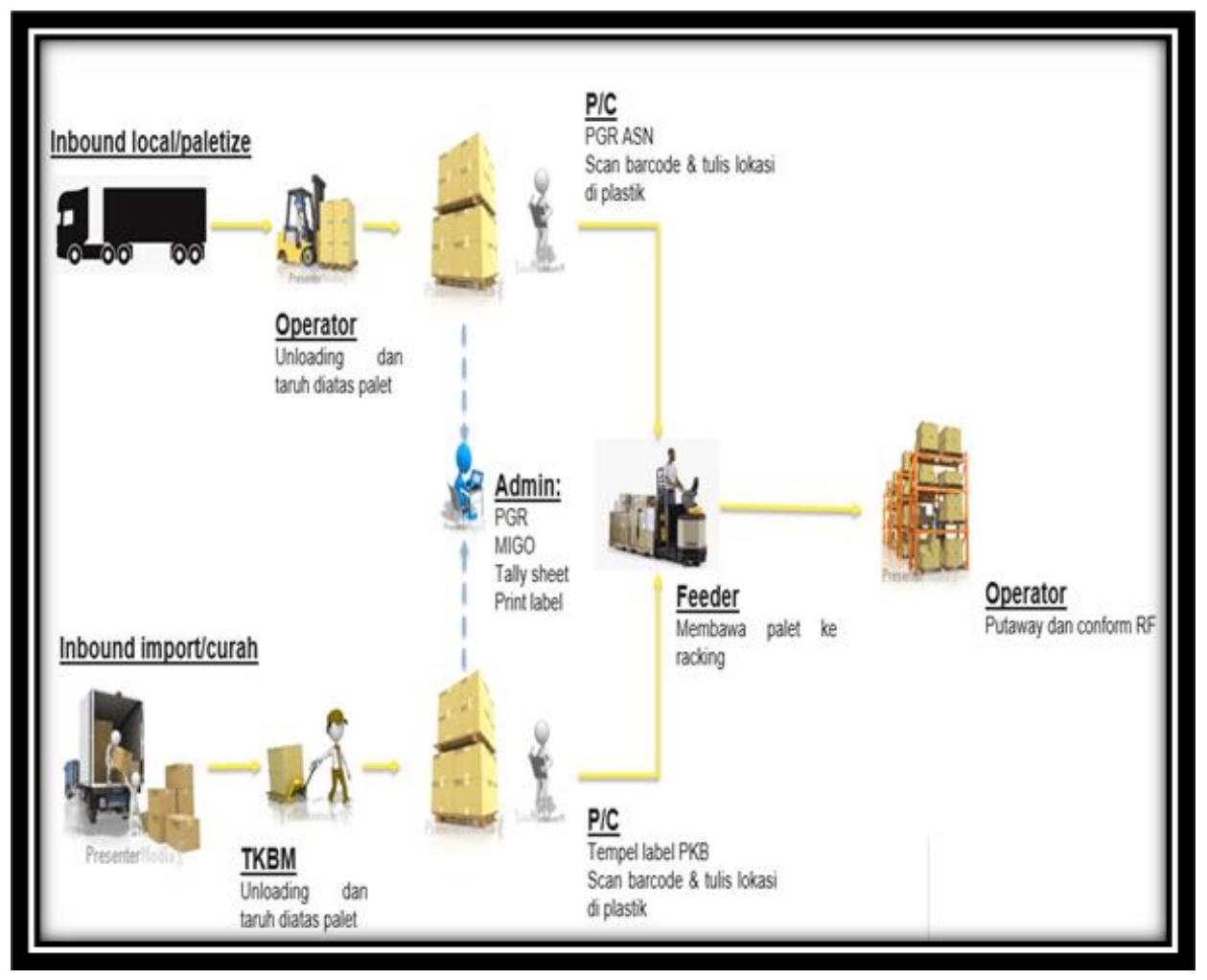

Gambar 2. Proses inbound 


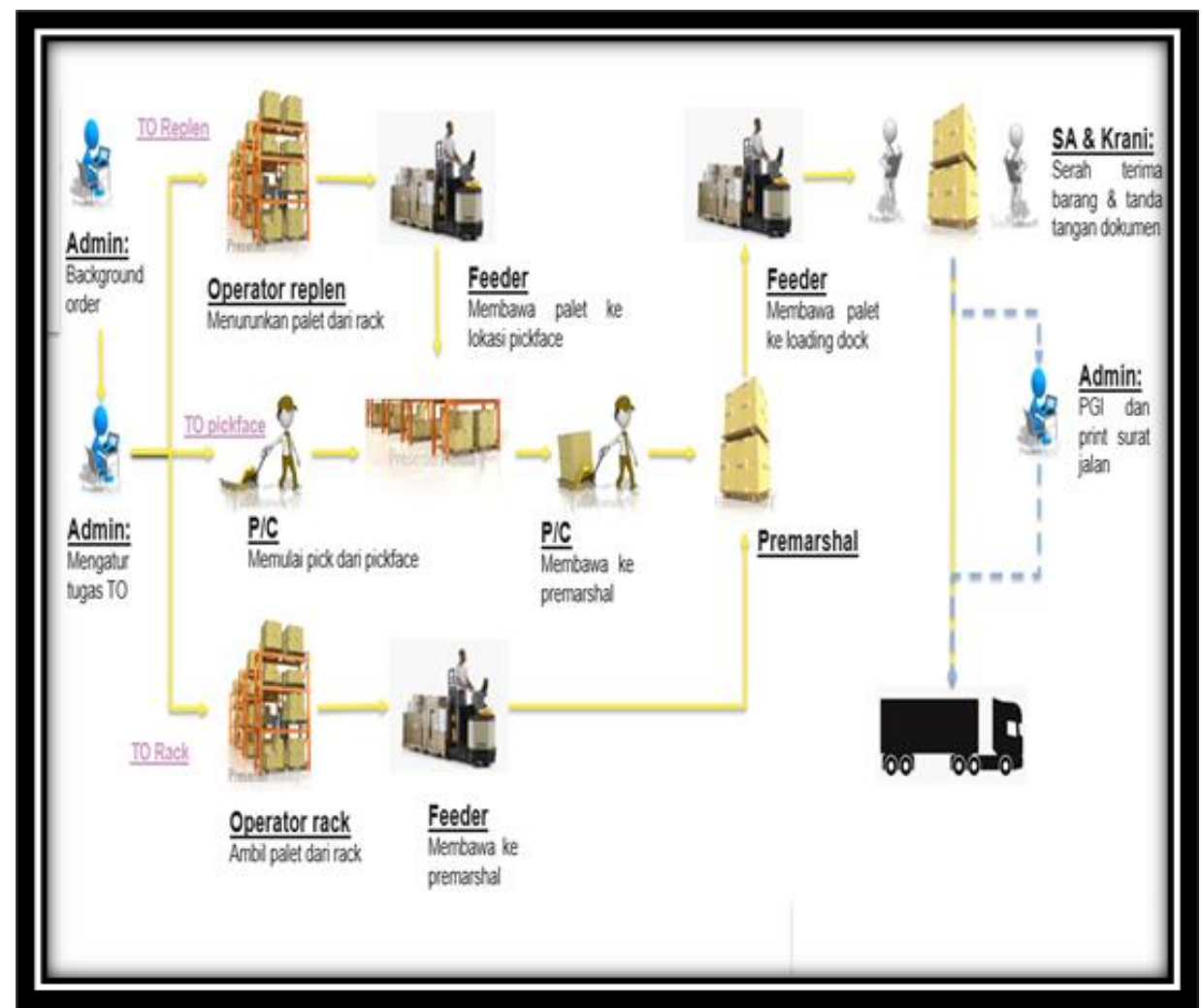

Gambar 3. Proses outbound

Tahap define merupakan tahap yang bertujuan untuk mengidentifikasi sumber sumber masalah dan mencari sasaran yang harus ditinjau proses kerjanya. Dalam tahap ini dapat dilakukan dengan menggunakan diagram SIPOC. Pada departemen operation zona 3 ini proses penyimpanan barang dilakukan per palet dan untuk proses picking dibedakan menjadi dua yaitu picking per palet dan per karton. Sementara untuk proses picking per pallet diambil langsung dari rak oleh operator reack truck sedangkan untuk picking per karton diambil secara manual oleh picker checker di lokasi stock karton atau pickface yang di-supply melalui proses replenisment yaitu proses restock barang dari lokasi racking ke lokasi stock pickface untuk proses picking per karton. Berikut ini merupakan diagram SIPOC dari departemen operation zona 3.

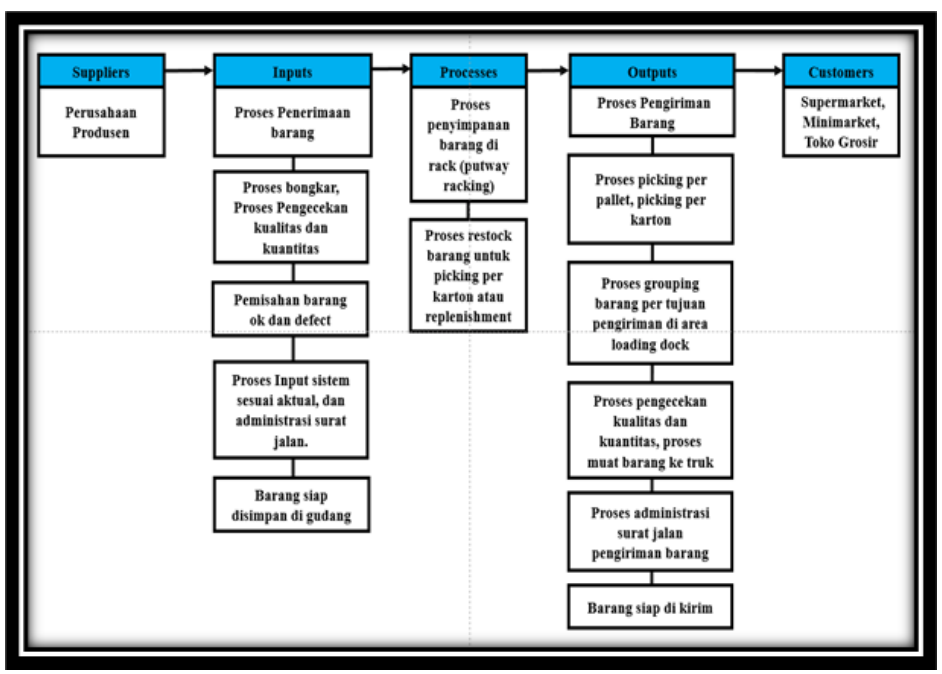

Gambar 4. Diagram SIPOC 
Langkah selanjutnya yaitu menentukan tingkat cacat produk. Berikut ini adalah data lima produk cacat tertinggi dari periode bulan juli sampai dengan desember tahun 2019 yang akan disajikan dalam bentuk tabel.

Tabel 1. Rekapitusi jumlah defect produk

\begin{tabular}{|c|c|c|c|c|c|c|c|c|}
\hline \multirow{2}{*}{ No } & \multirow{2}{*}{ Nama Produk } & \multicolumn{6}{|c|}{ Periode } & \multirow{2}{*}{ Total } \\
\hline & & 1 & 2 & 3 & 4 & 5 & 6 & \\
\hline 1 & ER180 & 270 & 850 & 757 & 364 & 86 & 36 & 2363 \\
\hline 2 & IA195 & 21 & 32 & 320 & 443 & 33 & 6 & 855 \\
\hline 3 & IA120 & 321 & 116 & 75 & 112 & 7 & 20 & 651 \\
\hline 4 & SL235 & 34 & 72 & 122 & 18 & 83 & 36 & 365 \\
\hline 5 & IA 220 & 50 & 69 & 54 & 56 & 110 & 15 & 354 \\
\hline 6 & Produk Lain & 901 & 1153 & 853 & 981 & 573 & 197 & 4658 \\
\hline \multicolumn{2}{|c|}{ Total Produk Cacat } & 1597 & 2292 & 2181 & 1974 & 892 & 310 & 9246 \\
\hline
\end{tabular}

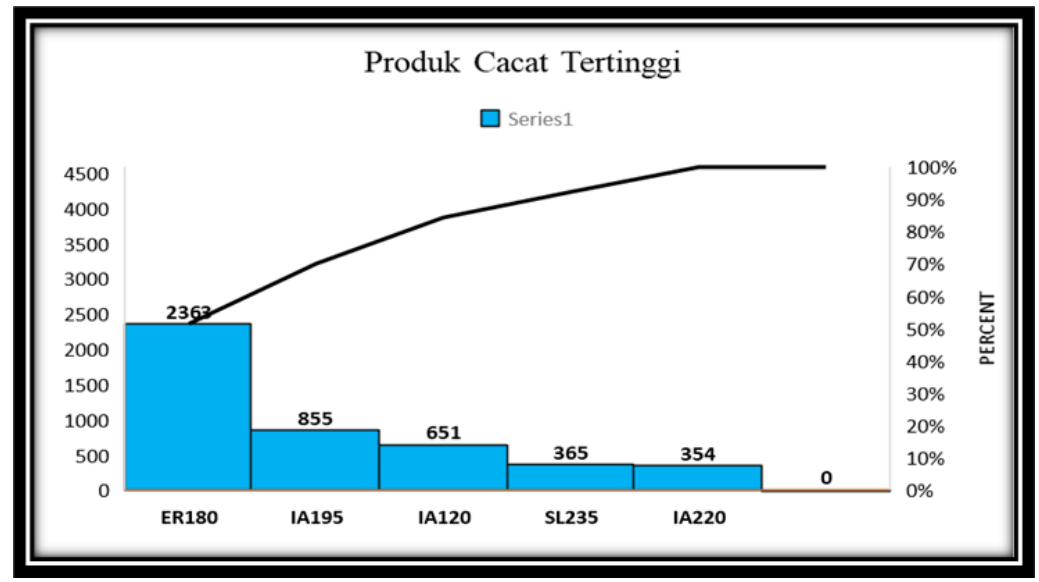

Gambar 5. Diagram pareto produk cacat tertinggi

Berdasarkan diagram pareto diatas maka diketahui bahwa produk ER180 merupakan produk yang mempunyai persentase defect tertinggi diantara produk lain yaitu sebanyak 52\%. Dari diagram pareto tersebut juga dapat dilihat bahwa total produk defect pada produk ER180 sama dengan empat produk yang lain jika dijumlahkan. Dengan demikian fokus produk yang akan dianalisa lebih lanjut yaitu produk ER180 saja.

Tahap measure merupakan tahap untuk menetapkan ukuran kinerja yaitu pengukuran tingkat sigma dan defect per million opportunities (DPMO). Defect Per Opportunity merupakan suatu ukuran yang menunjukan proporsi defect atas jumlah total peluang dalam sebuah kelompok (Arini, 2017). Diketahui jumlah total cacat dari lima produk cacat tertinggi pada periode juli sampai dengan desember 2019 sebanyak 4.588 karton. Sedangkan total penerimaan kelima produk tersebut sebanyak 4.941.692 karton dan lima produk dengan jumlah cacat tertinggi ini dijadikan CTQ potensial.

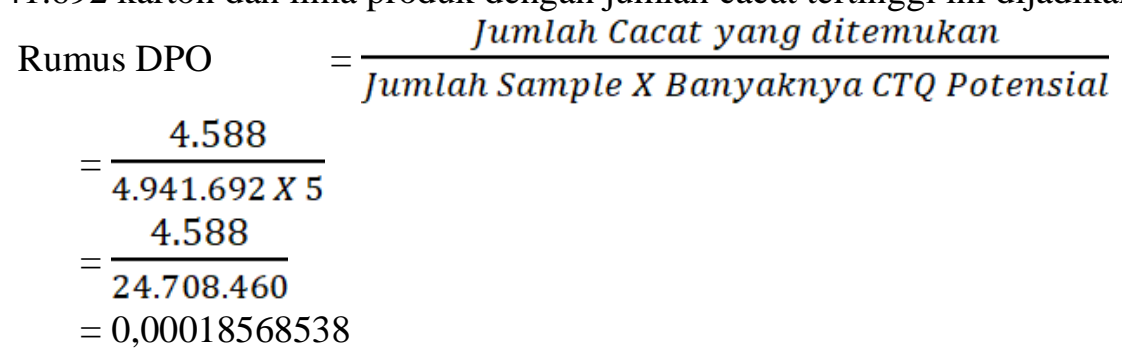




$$
\begin{aligned}
\text { DPMO } & =\text { DPO X 1.000.000 } \\
& =0,00018568538 \times 1.000 .000 \\
& =185,68538
\end{aligned}
$$

Berdasarkan perhitungan di atas maka dapat diketahui nilai rata-rata kesempatan untuk defect produk (DPMO) adalah sebesar 185,68538 kegagalan per satu juta atau jika dilihat dari tabel konversi six sigma dan tabel konversi Cost of Poor Quality berada pada level sigma sekitar 5,06 dengan tingkat COPQ sebesar 5-15\% dari total pendapatan.

Tahap Analyze menggunakan fault tree analysis. Berikut ini merupakan diagram fault tree analysis yang digunakan sebagai analisa sebab akibat dari produk yang memiliki nilai cacat tertinggi yaitu produk ER180.

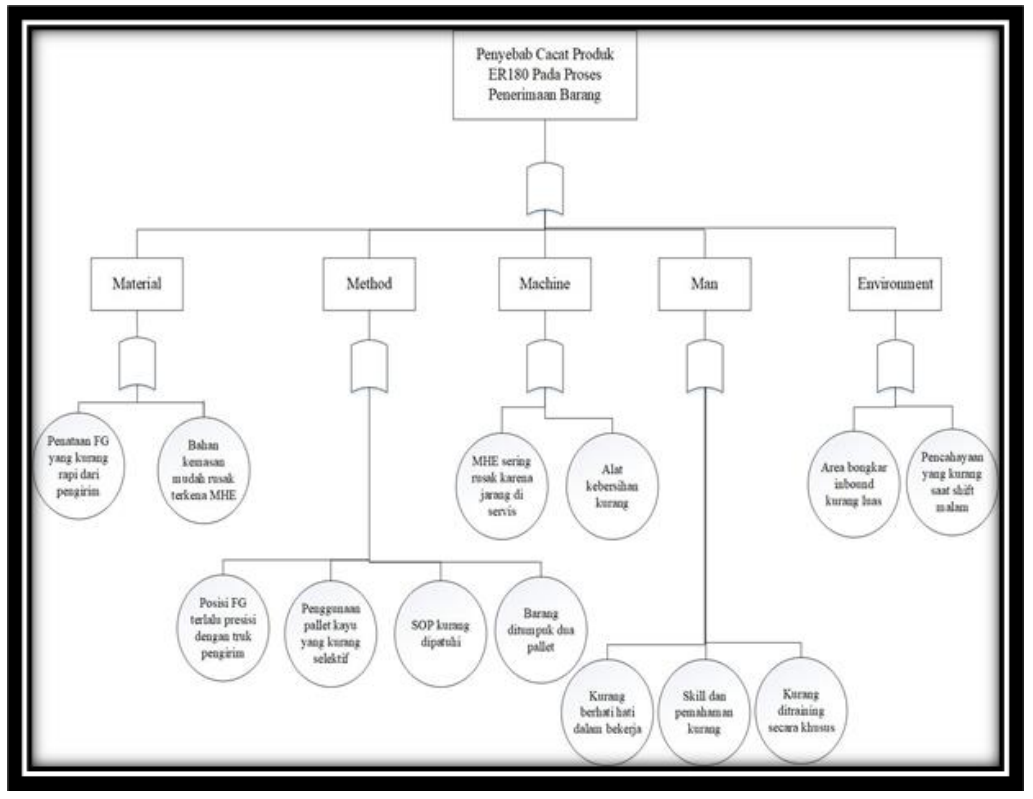

Gambar 6. Fault tree analysis penyebab produk cacat 
Selain menggunakan FTA dalam tahap anlyze juga menggunakan FMEA, dengan hasil sebagai berikut.

\section{Tabel 2. Perhitungan nilai RPN}

\begin{tabular}{|c|c|c|c|c|c|c|c|}
\hline $\begin{array}{c}\text { Mode Kegagalan } \\
\text { Potensial }\end{array}$ & $\begin{array}{c}\text { Efek Kegagalan } \\
\text { Potensial }\end{array}$ & Penyebab Kegagalan & $\mathbf{S}$ & $\mathbf{O}$ & $\mathbf{D}$ & RPN & Usulan Perbaikan \\
\hline \multirow{2}{*}{$\begin{array}{l}\text { Penerimaan Produk } \\
\text { pada checker inbound }\end{array}$} & $\begin{array}{l}\text { Ditemukan produk } \\
\text { dengan kemasan } \\
\text { polos }\end{array}$ & Kesalahan dari produsen & 2 & 8 & 1 & 16 & $\begin{array}{l}\text { Melaporkan ke pihak produsen agar di } \\
\text { identifikasi lebih lanjut pada proses } \\
\text { produksi. }\end{array}$ \\
\hline & $\begin{array}{l}\text { Ditemukan produk } \\
\text { busuk }\end{array}$ & $\begin{array}{l}\text { Kesalahan proses packing } \\
\text { produk yang kurang rapi oleh } \\
\text { produsen. }\end{array}$ & 2 & 7 & 1 & 14 & $\begin{array}{l}\text { Melaporkan ke pihak produsen agar di } \\
\text { identifikasi lebih lanjut pada proses packing } \\
\text { produk sebelum di kirim ke gudang. }\end{array}$ \\
\hline \multirow{2}{*}{$\begin{array}{l}\text { Unloading dari } \\
\text { kontainer ke area } \\
\text { penerimaan }\end{array}$} & $\begin{array}{l}\text { Ditemukan produk } \\
\text { bocor }\end{array}$ & $\begin{array}{l}\text { Produk terkena garpu forklift } \\
\text { dan kurangnya pencahayaan }\end{array}$ & 6 & 8 & 8 & 384 & $\begin{array}{l}\text { Penambahan lampu pencahayaan pada area } \\
\text { kerja. }\end{array}$ \\
\hline & $\begin{array}{l}\text { Ditemukan produk } \\
\text { dengan kemasan luar } \\
\text { rusak }\end{array}$ & $\begin{array}{l}\text { Produk terkena dinding } \\
\text { dinding kontainer saat } \\
\text { perjalanan menuju gudang }\end{array}$ & 5 & 5 & 3 & 75 & $\begin{array}{l}\text { Melaporkan ke pihak produsen dan } \\
\text { transporter agar di identifikasi lebih lanjut } \\
\text { pada proses pengiriman ke gudang. }\end{array}$ \\
\hline \multirow[b]{2}{*}{ Penggunaan pallet } & $\begin{array}{l}\text { Ditemukan produk } \\
\text { penyok }\end{array}$ & $\begin{array}{l}\text { Penggunaan pallet kayu yang } \\
\text { rusak }\end{array}$ & 8 & 8 & 9 & 576 & $\begin{array}{l}\text { Perlu adanya pemilihan pallet yang sesuai } \\
\text { standar sebelum digunakan. }\end{array}$ \\
\hline & $\begin{array}{l}\text { Ditemukan produk } \\
\text { dengan kemasan } \\
\text { rusak }\end{array}$ & $\begin{array}{l}\text { Penggunaan pallet kayu yang } \\
\text { rusak }\end{array}$ & 8 & 8 & 8 & 512 & $\begin{array}{l}\text { Perlu adanya pemilihan pallet yang sesuai } \\
\text { standar sebelum digunakan. }\end{array}$ \\
\hline Material Handling & $\begin{array}{l}\text { Produk terbentur } \\
\text { MHE }\end{array}$ & Operator MHE tidak hati hati & 9 & 9 & 8 & 648 & $\begin{array}{l}\text { Perlu dilakukan training agar pengetahuan } \\
\text { dan skill karyawan meningkat. }\end{array}$ \\
\hline \multirow[t]{2}{*}{$\begin{array}{l}\text { Area penyimpanan } \\
\text { sementara produk }\end{array}$} & \multirow[t]{2}{*}{$\begin{array}{l}\text { Produk akan saling } \\
\text { terbentur dan penyok }\end{array}$} & $\begin{array}{l}\text { Area penyimpanan produk } \\
\text { sementara kurang luas }\end{array}$ & 7 & 5 & 6 & 210 & $\begin{array}{l}\text { Perlu adanya pengontrolan terhadap } \\
\text { kapasitas gudang dengan jumlah produk } \\
\text { yang akan diterima. }\end{array}$ \\
\hline & & Produk ditumpuk dua pallet. & 5 & 2 & 6 & 60 & Tidak boleh menumpuk produk yang berat. \\
\hline \multirow{2}{*}{$\begin{array}{l}\text { Rak penyimpanan } \\
\text { produk }\end{array}$} & Produk terkena rak & $\begin{array}{l}\text { Operator MHE tidak hati hati } \\
\text { dan kurangnya pencahayaan }\end{array}$ & 8 & 8 & 9 & 576 & $\begin{array}{l}\text { Penambahan lampu pencahayaan pada area } \\
\text { kerja. }\end{array}$ \\
\hline & Produk terkena MHE & $\begin{array}{l}\text { Operator MHE tidak hati hati } \\
\text { dan kurangnya pencahayaan }\end{array}$ & 7 & 7 & 8 & 392 & $\begin{array}{l}\text { Penambahan lampu pencahayaan pada area } \\
\text { kerja. }\end{array}$ \\
\hline
\end{tabular}




\section{Pembahasan}

Tahap improve merupakan langkah perbaikan yang harus dilakukan oleh pihak perusahaan agar dapat mengurangi tingkat kecacatan produk. Berdasarkan analisa yang sudah dilakukan pada tahap sebelumnya, kecacatan produk yang terjadi disebabkan oleh banyak faktor diantaranya material, metode, mesin, manusia dan lingkungan. Bentuk usulan perbaikan yang akan diberikan kepada pihak perusahaan ditentukan berdasarkan nilai RPN tertinggi sampai terendah yang sudah dihitung sebelumnya. Hal ini bertujuan agar pihak perusahaan dapat memprioritaskan langkah-langkah perbaikan yang harus terlebih dahulu dilakukan. Adapun usulan perbaikan yang dapat dilakukan oleh pihak perusahaan dalam menangani masalah kecacatan produk adalah sebagai berikut:

Tabel 3. Usulan perbaikan penyebab kecacatan produk

\begin{tabular}{|c|c|c|}
\hline Penyebab Kegagalan & RPN & Usulan Perbaikan \\
\hline Operator MHE tidak hati hati & 648 & $\begin{array}{l}\text { Perlu dilakukan training agar pengetahuan dan } \\
\text { skill karyawan meningkat. }\end{array}$ \\
\hline $\begin{array}{l}\text { Penggunaan pallet kayu yang } \\
\text { rusak }\end{array}$ & 576 & $\begin{array}{l}\text { Perlu adanya pemilihan pallet yang sesuai } \\
\text { standar sebelum digunakan. }\end{array}$ \\
\hline $\begin{array}{l}\text { Operator MHE tidak hati hati } \\
\text { dan kurangnya pencahayaan }\end{array}$ & 576 & $\begin{array}{l}\text { Penambahan lampu pencahayaan pada area } \\
\text { kerja. }\end{array}$ \\
\hline $\begin{array}{l}\text { Produk terkena garpu forklift } \\
\text { dan kurangnya pencahayaan }\end{array}$ & 384 & $\begin{array}{l}\text { Penambahan lampu pencahayaan pada area } \\
\text { kerja. }\end{array}$ \\
\hline $\begin{array}{l}\text { Area penyimpanan produk } \\
\text { sementara kurang luas }\end{array}$ & 210 & $\begin{array}{l}\text { Perlu adanya pengontrolan terhadap kapasitas } \\
\text { gudang dengan jumlah produk yang akan } \\
\text { diterima. }\end{array}$ \\
\hline $\begin{array}{l}\text { Produk terkena dinding dinding } \\
\text { kontainer saat perjalanan } \\
\text { menuju gudang }\end{array}$ & 75 & $\begin{array}{l}\text { Melaporkan ke pihak produsen dan transporter } \\
\text { agar di identifikasi lebih lanjut pada proses } \\
\text { pengiriman ke gudang. }\end{array}$ \\
\hline Produk ditumpuk dua pallet. & 60 & Tidak boleh menumpuk produk yang berat. \\
\hline Kesalahan dari produsen & 16 & $\begin{array}{l}\text { Melaporkan ke pihak produsen agar di } \\
\text { identifikasi lebih lanjut pada proses produksi. }\end{array}$ \\
\hline $\begin{array}{l}\text { Kesalahan proses packing } \\
\text { produk yang kurang rapi oleh } \\
\text { produsen. }\end{array}$ & 14 & $\begin{array}{l}\text { Melaporkan ke pihak produsen agar di } \\
\text { identifikasi lebih lanjut pada proses packing } \\
\text { produk sebelum di kirim ke gudang. }\end{array}$ \\
\hline
\end{tabular}

\section{KESIMPULAN}

Berdasarkan hasil penelitian dan pengolahan data dengan pendekatan konsep six sigma DMAIC dan metode fault tree analysis serta failure mode and effect analysis sebagai upaya dalam pengendalian kualitas dan identifikasi penyebab produk defect pada Perusahaan Logistics departemen operation zona 3, maka dapat diperoleh kesimpulan sebagai berikut:

Berdasarkan hasil pengolahan dan pembahasan yang telah dilakukan pada bab sebelumnya, diketahui bahwa terdapat lima jenis produk dengan jumlah defect tertinggi selama periode enam bulan terakhir yaitu ER180 sebanyak 2363 karton, IA195 sebanyak 855 karton, IA120 sebanyak 651 karton, SL235 dan IA220 yang masing masing jumlahnya sebanyak 365 dan 354 karton. 
Berdasarkan hasil pengolahan perhitungan DPMO dan sigma selama periode bulan juli sampai dengan desember 2019 diperoleh rata-rata nilai DPMO sebesar 185,68538 kegagalan per satu juta dan level sigmanya sekitar 5,06 dengan tingkat COPQ sebesar 5-15\% dari total pendapatan.

Berdasarkan analisa pada diagram fault tree analysis maka diketahui beberapa sumber-sumber penyebab kecacatan produk yang disebabkan karena faktor material, metode, mesin, manusia dan lingkungan.

Berdasarkan analisa data menggunakan failure mode and effect analysis terdapat enam jenis cacat produk yaitu kemasan penyok, karton luar rusak, produk bocor, produk busuk, dimensi produk tidak sesuai dan kemasan polos.

Dengan menggunakan failure mode and effect analysis maka diketahui tiga penyebab utama terjadinya produk defect berdasarkan akumulasi nilai RPN yaitu faktor operator MHE yang tidak hati hati, penggunaan palet kayu yang rusak dan kurangnya pencahayaan di area kerja.

Beberapa usulan perbaikan kualitas yang dapat diberikan kepada pihak perusahaan yaitu perlu dilakukan training agar pengetahuan dan skill karyawan meningkat, perlu adanya pemilihan palet yang sesuai standar sebelum digunakan dan penambahan lampu pencahayaan pada area kerja.

Penelitian selanjutnya diharapkan dapat menerapkan usulan-usulan perbaikan serta melakukan analisa perbandingan antara sebelum dan sesudah perbaikan.

\section{DAFTAR PUSTAKA}

Irwan, \& Didi Haryono. (2015). Pengendalian Kualitas Statistik (Pendekatan Teoritis dan Aplikatif). Bandung: Alfabeta.

Pratama, Farid Setia \& Suhartini. (2019). Analisis Kecacatan Produk dengan Metode Seven Tools dan FTA dengan Mempertimbangkan Nilai Risiko dengan Metode FMEA. Jurnal Senopati: Sustainability, Ergonomics, Optimization, and Application of Industrial Engineering, 1(1): 4351. 